\title{
THE RELATIONSHIP BETWEEN INNOVATIONS AND QUALITY MANAGEMENT SYSTEM
}

\author{
Aleksandar Vujović, Jelena Jovanović, Zdravko Krivokapić, Sanja Peković, Mirko Soković, Davorin Kramar
}

Original scientific paper

The paper is focused on analysis concerning Quality Management System (QMS) and innovation performance relationship in Montenegrin firms. In accordance with that we firstly present literature about innovations performance in ISO 9001 certified firms around the world. Some of these empirical studies prove a positive influence of ISO 9001 on innovation, while the others provide opposite results. In addition, we performed empirical analysis on data extracted from survey of Montenegrin firms. Using an Ordinary Least Square regression (OLS) we show that ISO 9000 certification influences innovation performance positively.

Keywords: innovations performance; ordinary least square regression (OLS); quality management system

Odnos inovacija i sustava upravljanja kvalitetom

Izvorni znanstveni članka

Rad je fokusiran na analizu odnosa između sustava upravljanja kvalitetom i inovacijskih performansi u crnogorskim firmama. S tim u vezi smo u prvom dijelu rada razmotrili inovacijske performanse svjetskih firmi certificiranih prema ISO 9001. Pojedina empirijska istraživanja dokazuju pozitivan utjecaj certifikata ISO 9001 na inovacije, dok druga istraživanja daju suprotne rezultate. Pored toga, izveli smo empirijske analize rezultata dobivenih anketiranjem crnogorskih firmi. Primjenom Ordinary Least Square regression (OLS) metode pokazali smo da certifikat ISO 9000 ima pozitivan utjecaj na inovacije.

Ključne riječi: inovacijske performanse; metoda najmanjih kvadrata regresije; sustav upravljanja kvalitetom

\section{Introduction}

Improvement of organizational performances, in the conditions of markets and economies uniting, represents the primary objective of every successful organization with the aim of improving competition and financial stability. One of the models that ensures organisational sustainability and improvement of performances is the model ISO 9001. Analysis of literature sources indicates that numerous research works are focussed on the analysis of benefits of the ISO 9000 standard series [8, 19, 20], while the largest number of authors agree that when consistently implemented, this series of standards brings manifold benefits for the organisation and that it stimulates innovativeness as the key lever of organisational sustainability and competitiveness $[8,19$, 20]. Also, this series of standards stimulates management of inconsistencies with the aim of prevention measures planning and implementation, which according to numerous authors is a prerequisite for sustainability, improvement of organisational performances and innovation [1, 4, 9, 23, 24, 29]. Timely, the aim of this paper is to carry out an analysis of the influence of ISO 9001 standard on the development of innovativeness.

It is very important to adopt and interpret correctly the concept of innovation i.e. to deviate from the earlier understanding of innovation as a technical solution. In line with the new understanding of the concept of innovation, it can be concluded that besides the concept of an entirely new solution innovation also implies implementation of some well-known solution from the global level in the local environment in which it is an absolute novelty that brings benefits, even those of financial nature $[4,15]$. Facts and circumstances defined in this manner are an incentive for authors of the paper to make a comprehensive research with the objectives to obtain new knowledge aimed at improving organisational performances and to ensure stimulation for development of innovations.

Thanks to data base, we provide the analysis of this relationship between QMS and innovation performance in developing country such as Montenegro. In this sense, finding tool that can further stimulate innovation performance is very important especially for developing countries since their innovation performance lags significantly behind developed countries.

\section{Literature review}

Innovativeness and organisational creativity must be the basic underlying principles for any business doing in any area and in the systems of any size. Improvement of business doing based on the implementation of entirely new solutions and adoption of contemporary technologies is the base for improvement of organisational performances and creating of additional value [17].

Knowledge management as an important segment of the overall management system is a special variable that has a key importance for organisational recognisability on the market [6]. This is also why numerous contemporary organisations recognize this system through implementation of the role of knowledge manager, and frequently the value of organisations on the market is recognized through the level of knowledge possessed by its employees. The procedure that promotes the principle of leadership, stronger interaction of employees and the management and the establishment of undivided responsibilities and joint action towards the achievement of the same goal, lead to innovativeness, improvement of organisational performances and ensure satisfaction and user loyalty [26, 28].

This kind of modern understanding of innovativeness is supported also by the principles and requirements of the ISO 9000 standard series, which precisely through development of this standard stimulate development of 
measurable progressive objectives, whose achievement must be proved through this system audit, which in fact represents an improvement of organisational performances. In this manner it is ensured that besides the needed effectiveness the system also has the obligatory efficiency, i.e. that it can prove its development and improvements. Numerous researchers in this area, and the philosophy of the standard series indicate the need for continuous small improvements, and not occasional major technological undertakings, which usually imply huge investments and transformations, i.e. lead to the obligation of re-engineering as a very expensive, time-consuming procedure with an uncertain outcome $[18,27]$.

Deepening in this direction goes through adoption of the principle of Total Quality Management or development and assessment of the system according to some of the models of business excellence $[11,12,14]$, as a guarantee of improvement of organisational performances and achievement of financial and other benefits [10].

There are frequently cases when quality management system is implemented for the needs of obtaining a certificate and frequently this system creates a huge amount of bureaucracy and documents. Still, most authors agree that this system, in particular if correctly implemented in line with the obligation of defining progressive and measurable objectives and periodic proving of their achievements, is a system which leads to innovativeness and is indeed an efficient system that improves organisational performances [10] and in particular so taking into account the fact that ISO 9000 series is a system based on the best world practices $[3,16]$.

According to the majority of authors innovations management and quality management system are two complementary systems ensuring organisational competitiveness and efficiency on the condition of consistent respect of the leadership principle, strictly defined responsibility and measurement of the level of achievement of progressive objectives [7].

Also, a smaller number of studies and researchers indicate the need for prudence when implementing norms for employees and adopting a uniform approach, as this could lead to reduction of inventiveness [13], which is still incompatible with the fact that it is precisely dedication of employees to the norms and procedures that represents the base for development of knowledge as the key prerequisite for organisational sustainability and development [5].

Similar results are reached by Baronien and Neverauskas [2] analysing 194 organizations from Australia.

Due to the conflicting conclusion concerning the relationship between QMS and innovation performance, we want to further understand their link. Therefore, we set up the following hypothesis:

H1: The adoption of QMS is associated with greater innovation performance.

\section{Empirical analysis \\ 3.1 The database}

The database for this research was created based on a research of 119 organisations from all areas of Montenegro (north, seaside and the central part of the country). A survey including 31 questions was created with this objective, without specific time limit for filling it in. It was conceived so that answers and information are obtained with regard to the activities which organisations are conducting in the area of innovations development and stimulating creativity. The research was conducted in the period of four months by the end of 2011 .

\subsection{Dependent and Independent Variables}

New or improved product/service. The dependent variable denoted New or improved product/service presents continuous variables indicating the number of firm's new or improved products/services.

ISO 9000. To test our main hypothesis of the paper, namely that the quality standards are positively associated with innovation performance, we use the variable denoted ISO 9000 , which is a binary variable, coded 1 if the firm has ISO 9000 certification.

\subsection{Controls}

In order to ensure the importance of variables that can influence the decision of the organisation to invest in innovations, the variables related to the following characteristics have been observed: ownership, financial resources, size, sector of activity, [20]. Additionally, as control variables we introduce information regarding the innovation meetings that are organized inside a firm as well as firm's organization of decision making.

Tab. 1 shows variables used for estimation, their definitions and sample statistics. No problem of multicollinearity was detected (Appendix 1).

Table 1 Definition of variables and sample statistics

\begin{tabular}{|c|c|c|c|}
\hline Variable & Definition & $\stackrel{*}{\stackrel{*}{\Xi}}$ & 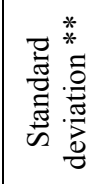 \\
\hline \multicolumn{4}{|c|}{ Dependent variables } \\
\hline $\begin{array}{l}\text { New or improved } \\
\text { product/service }\end{array}$ & \begin{tabular}{|l|} 
Number of new or \\
improved product/service \\
(Continuous variable)
\end{tabular} & 4,36 & 3,80 \\
\hline \multicolumn{4}{|c|}{ Independent variables } \\
\hline ISO 9000 & $\begin{array}{l}\text { Having ISO } 9000 \\
\text { certification } \\
\text { Dummy variable }(=1 \text { if } \\
\text { certified })\end{array}$ & 0,50 & 0,50 \\
\hline \multicolumn{4}{|l|}{ Control variables } \\
\hline Size & $\begin{array}{l}\text { The firm's size } \\
\text { (Continuous variable) }\end{array}$ & 156,49 & 240,38 \\
\hline $\begin{array}{l}\text { Manufacturing, } \\
\text { Construction, } \\
\text { Trade, } \\
\text { Service }\end{array}$ & $\begin{array}{l}\text { The firm belongs to one } \\
\text { of the following sectors: } \\
\text { - Manufacturing } \\
\text { - Construction } \\
\text { - Trade } \\
\text { - Service (ref)*** } \\
\text { Dummy variables (=1 if } \\
\text { yes) }\end{array}$ & $\begin{array}{l}0,33 \\
0,11 \\
0,21 \\
0,35\end{array}$ & $\begin{array}{l}0,47 \\
0,31 \\
0,41 \\
0,48\end{array}$ \\
\hline $\begin{array}{l}\text { Private, } \\
\text { Public, } \\
\text { Mix }\end{array}$ & $\begin{array}{l}\text { The firm is: } \\
\text { - Private } \\
\text { - Public (ref)*** } \\
\text { - Mix (ref)*** } \\
\text { Dummy variables (=1 if } \\
\text { yes) }\end{array}$ & $\begin{array}{l}0,75 \\
0,17 \\
0,08\end{array}$ & $\begin{array}{l}0,43 \\
0,37 \\
0,28\end{array}$ \\
\hline
\end{tabular}


Table 1 Definition of variables and sample statistics (continuation)

\begin{tabular}{|c|c|c|c|}
\hline Variable & Definition & $\stackrel{\text { * }}{\stackrel{*}{\Xi}}$ & 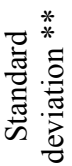 \\
\hline \multicolumn{4}{|c|}{ Control variables } \\
\hline Profit & $\begin{array}{l}\text { The profit of a firm is: } \\
\text { - Up to } 100000 €(=1) \\
\text { - } 100000 \div 500000 €(=2) \\
\text { - } 500000 \div 2500000(=3) \\
\text { - } 2500000 \div 10000000(=4) \\
\text { - More than } 10000000(=5) \\
\text { Count variable }\end{array}$ & 3,35 & 1,29 \\
\hline Inno Profit & $\begin{array}{l}\text { Part of profit obtained from new or } \\
\text { improved product/service: } \\
\text { - } 0(=1) \\
\text { - Up to } 20 \%(=2) \\
\text { - } 20 \div 49 \%(=3) \\
\text { - } 50 \div 69 \%(4) \\
\text { - More than } 70 \%(=5) \\
\text { Count variable } \\
\end{array}$ & 2,18 & 0,96 \\
\hline Meeting & $\begin{array}{l}\text { Innovation-oriented meetings are } \\
\text { held: } \\
\text { - Weekly }(=5) \\
\text { - Monthly }(=4) \\
\text { - Each } 6 \text { months }(=3) \\
\text { - Each year }(=2) \\
\text { - Never }(=1) \\
\text { Count variable }\end{array}$ & 2,78 & 1,55 \\
\hline $\begin{array}{l}\text { Decision } \\
\text { Making }\end{array}$ & $\begin{array}{l}\text { The innovation decisions are made } \\
\text { by: } \\
\text { - D1: Top Management } \\
\text { - D2: Top Management and } \\
\text { Managers } \\
\text { - D3: All levels of a firm are } \\
\text { involved } \\
\text { - D4: Employees develop ideas } \\
\text { without managers } \\
\text { - D5: Spontaneously (ref). } * * *\end{array}$ & $\begin{array}{l}0,17 \\
0,37 \\
0,26 \\
0,03 \\
0,17 \\
\end{array}$ & $\begin{array}{l}0,37 \\
0,48 \\
0,44 \\
0,18 \\
0,38\end{array}$ \\
\hline
\end{tabular}

* The mean (also know as average), is obtained by dividing the sum of observed values by the number of observations.

** Standard Deviation (SD) measures the amount of variation or dispersion from the average.

*** The reference group is compared to the group of interest.

\subsection{Estimation strategy}

Using an Ordinary Least Square regression (OLS), we investigate the effect of ISO 9000 certification on the number of new or improved products/services. We now have:

$y_{i}=X_{i} a+e_{i}$,

where: $y_{i}-$ represents the number of new or improved products/services; $X_{i}$ - the vectors of the following variables: ISO 9000 certification size, sector of activity, ownership, profit, profit from innovation, meeting and participation in decision making; $e_{i}-$ error term.

\section{Results}

The results of the OLS estimation are presented in Tab. 2. In Tab. 2, we present R-square which is the coefficient of determination indicating goodness-of-fit of the regression. The R-square of the model is $38 \%$ ( $p<$
0,001 ), which can be considered, in terms of statistical fit of a model, as a satisfactory value (according to Berman, 2002).

The results show that the hypothesized positive relationship between ISO 9000 certification and innovation performance is supported since the coefficient of ISO standard on innovation activities is positive and statistically significant $(p<0,05)$.

Table 2 Definition of variables and sample statistics

\begin{tabular}{|c|c|c|c|}
\hline \multirow[b]{2}{*}{ Variables } & \multicolumn{3}{|c|}{ New or improved product/service } \\
\hline & Estimate & $\begin{array}{l}\text { Probability } \\
\qquad(P>|t|)\end{array}$ & Standard Error \\
\hline Quality & $1,30 * *$ & 0,04 & $(0,64)$ \\
\hline Size & $-0,00$ & 0,49 & $(0,00)$ \\
\hline Manufacturing & 1,00 & 0,22 & $(0,81)$ \\
\hline Construction & $-0,35$ & 0,75 & $(1,10)$ \\
\hline Trade & 0,35 & 0,70 & $(0,92)$ \\
\hline Private Ownership & $-0,51$ & 0,55 & $(0,985)$ \\
\hline Profit & 0,42 & 0,13 & $(0,27)$ \\
\hline Inno Profit & $2,02 * * *$ & 0,00 & $(0,33)$ \\
\hline Meeting & $0,64 * * *$ & 0,00 & $(0,22)$ \\
\hline Decision 1 & $-2,00 *$ & 0,08 & $(1,13)$ \\
\hline Decision 2 & 0,15 & 0,87 & $(0,94)$ \\
\hline Decision 3 & $-1,98$ & 0,35 & $(1,04)$ \\
\hline Decision 4 & 1,27 & 0,48 & $(1,80)$ \\
\hline Constant & $-3,21 * * *$ & 0,026 & $(1,42)$ \\
\hline \multicolumn{4}{|c|}{ Test of global statistic quality } \\
\hline$R^{2}$ & \multicolumn{3}{|c|}{0,38} \\
\hline$F(13,105)$ & \multicolumn{3}{|c|}{5,01} \\
\hline Prob $>F$ & \multicolumn{3}{|c|}{0,00} \\
\hline Observations & \multicolumn{3}{|c|}{119} \\
\hline
\end{tabular}

* Indicates parameter significance at the $10 \%$ level.

** Indicates parameter significance at the $5 \%$ level.

*** Indicates parameter significance at the $1 \%$ level.

Our findings are thus consistent with previous studies concluding that firm's quality orientation boosts firm innovation activities $[20,21,22,25]$. Therefore, we may suggest that implementation of quality management standards creates a productive environment for innovation because it includes principles that are congruent with innovation [20]. As for control variables, estimation results show that profit obtained from innovation and having regular innovation meetings also influence positively improvement in innovation activities in terms of the number of new or improved products/services. It can be seen that the coefficients for both variables are significant at $1 \%$. Actually, as firm realizes the benefit that could be gained from innovation activities, it would be more motivated to improve its innovation performance. Moreover, the positive effect of innovation oriented meetings could be explained by the fact that attendance at meetings stimulates adoption of innovations through learning opportunities [19]. The negative effect of variable decision 1 (which indicates that only Top Management makes decision) confirms once again the importance that all levels of firm are necessary in order to improve innovation performance.

Furthermore, we may notice that other variables, such as size, sector of activity (including manufacturing, 
construction trade), private ownership, profit, decision2, decision 3 and decision4, are not significant in our model.

\section{Conclusion}

Development and investment into innovativeness and implementation of a system approach in this sense is by all means a prerequisite for development of organisational performances, a prerequisite for competitiveness and survival at the market. The overall organisational system of management as well as organisation strategy, as essential components must implement sub-systems of planning, development and innovation management. It is precisely the quality management system that represents the pillar or the base for stimulating innovative development and creative thinking, especially based on the promotion of importance and consistent respect of the principle of leadership, small incremental improvement and measuring of the level of achievement of particular objectives at the level of each process.

But empirical studies about link between ISO 9001 and innovations present conflicting results. Some empirical studies prove a positive influence of ISO 9001 on innovation, while the others prove opposite results. In accordance with that our research is focused to additional analysis relating this relationship based on Montenegrin firms.

The results show that the hypothesized positive relationship between ISO 9000 certification and innovation performance is supported since the coefficient of ISO standard on innovation activities is positive and statistically significant. Therefore, we may suggest that implementation of Quality Management System (ISO 9001) creates a productive environment for innovation because it includes principles that are congruent with innovation. These findings should stimulate further Montenegrin firms to adopt quality practices and at the same time become more innovative. However, focusing only on one country limits our conclusion and underlines the need to investigate whether other countries have the same experiences.

Note: The responsible translator for English language is Urška Letonja Grgeta, Videm, Slovenia.

\section{References}

[1] Abraham, M.; Crawford, J.; Carter, D.; Mazotta, F. Management decisions for effective ISO 9000 accreditation. // Management Decision. 38, 3(2000), pp. 182-193. DOI: $10.1108 / E U M 0000000005346$

[2] Baronien, L.; Neverauskas, B. The Role of Quality Management in the Process of Innovation Development. // Engineering Economics. 43, 3(2005), pp. 15-21.

[3] Bugdol, M. The implementation of the TQM philosophy in Poland. // The TQM Magazine. 17, 2(2005), pp. 113-120. DOI: 10.1108/09544780510583191

[4] Casadesus, M.; Jimenez, G. The benefits of the implementation of the ISO 9000 standard: empirical research in 288 Spanish companies, The TQM Magazine, 12, 6(2000), pp. 432-441. DOI: 10.1108/09544780010351751

[5] Eccles, R.; Pyburn, J. Creating a comprehensive system to measure performance. // Management Accounting. 74, 4(2002), pp. 41-44.
[6] Evans, R.; Lindsay, M. The management and control of quality, St. Paul, MN, 1994.

[7] Feng, J.; Prajogo, D. I.; Tan, K. C.; Sohal, A. S. The impact of TQM practices on performance-A comparative study between Australian and Singaporean organizations. // European Journal of Innovation Management. 9, 3(2006), pp. 269-278. DOI: 10.1108/14601060610678149

[8] Grolleau, G.; Mzoughi N.; Pekovic, S. Do Quality and Environmental-Related Standards Improve French Firms' Performance. // Environmental and Resource Economics. 54, 4(2013), pp. 525-548. DOI: 10.1007/s10640-012-9604-0

[9] Gupta, A. Quality management practices of ISO vs non ISO companies: a case of Indian industry. // Industrial Management and Data Systems. 100, 9(2000), pp. 451-455. DOI: 10.1108/02635570010358357

[10] Haar, J. M. Predicting total quality management adoption in New Zealand-The moderating effect of organizational size. // Journal of Enterprise Information Management. 21, 2(2008), pp. 162-178. DOI: 10.1108/17410390810851408

[11] Imai, M. Kaizen: The key to Japan's Competitive Success, New York: Random House, 1986.

[12] Jha, S.; Noori, H.; Michela, L. The dynamics of continious improvement: alining organizational attributes and activities for quality and productivity. // International journal of Quality Science. 1, 804(1996), pp. 19-47.

[13] Kanji, K. An integrated approach of organizational excellence, Retrieved from: http://www.gopal-kanji.com, 2001.

[14] Koc, T. The impact of ISO 9001 quality management systems on manufacturing. // Journal of Materials Processing Technology. 186, 1-3(2007), pp. 207-213.

[15] Krivokapic, Z.; Vujovic, A.; Jovanović, J.; Pekovic S.; Petrovic, S. The influence of QMS on development of innovation. // Paper presented at the 7th International conference ICQME 2012 (Quality, Management, Environment, Education, Engineering), Tivat, Montenegro, 2012.

[16] Kwai-Sang, C.; Kit- Fai, P.; Henry, L. Development of a knowledge - based self - assessment system for measuring organisational performance. // Expert systems with application. 24, 4(2003), pp. 443-455. DOI: 10.1016/S09574174(02)00192-6

[17] Lascelles, M.; Dale, G. Levelling out the future. // Total Quality Management. 2, 6(1991), pp. 325-330. DOI: 10.1108/09544789110033970

[18] Nair, A.; Boulton, W. R. Innovation oriented operations strategy typology and stage based model. // International Journal of Operations and Production Management. 28, 8(2008), pp 748-771. DOI: 10.1108/01443570810888599

[19] Pekovic, S. What Motives Firms to Seek ISO 9000 Certification: Comparative approach of French Manufacturing and Services Industries. // Journal of Economic Issues. 44, 4(2010), pp. 895-914. DOI: 10.2753/JEI0021-3624440403

[20] Pekovic, S.; Galia, F. From Quality to Innovation: Evidence from French Employer Survey. // Technovation. 29, 12(2009), pp. 829-842. DOl: 10.1016/j.technovation.2009.08.002

[21] Perdomo-Ortiz, J.; González-Benito, J.; Galende, J. Total quality managementas a forerunner of business innovation capability. // Technovation. 26, 10(2006), pp. 1170-1185. DOI: 10.1016/j.technovation.2005.09.008

[22] Prajogo, D. I.; Hong, S. W. The effect of TQM on performance in $R \& D$ environments: a perspective from South Korean firms. // Technovation. 28, 12(2008), pp. 855-863. DOI: 10.1016/j.technovation.2008.06.001

[23] Romano, P. ISO 9000: what is its impact on performance? // Quality Management Journal. 7, 3(2000), pp. 38-56.

[24] Santos, L.; Escanciano, C. Benefits of the ISO 9000:1994 system. Some considerations to reinforce competitive 
advantage. // International Journal of Quality \& Reliability Management. 19, 2(2002), pp. 321-344. DOI $10.1108 / 02656710210415703$

[25] Santos-Vijande, M. L. \& Álvarez-González, L. Innovativeness and organizational innovation in total quality oriented firms: the moderating role of market turbulence. // Technovation. 27, 9(2007), pp. 514-532. DOI: 10.1016/j.technovation.2007.05.014

[26] Sila, I.; Ebrahimpour, M. An investigation of the total quality management survey based research published between 1989 and 2002. // International Journal of Quality and Reliability Management. 19, 7(2002), pp. 902-970. DOI: 10.1108/02656710210434801

[27] Svensson, G. Sustainable quality management: a strategic perspective. // The TQM Magazine. 18, 1(2006), pp. 22-29. DOI: $10.1108 / 09544780610637668$

[28] Vujovic, A. Poboljšavanje performansi poslovnih procesa na bazi sistema menadžmenta primjenom alata vještačke inteligencije (Doktorska disertacija), Univerzitet Crne Gore, 2006.

[29] Withers, B.; Ebrahimpour, M. Does ISO 9000 affect the dimensions of quality used for competitive advantage? // European Management Journal. 18, 4(2000), pp. 431-443. DOI: 10.1016/S0263-2373(00)00032-3

\section{Authors' addresses}

\section{Aleksandar Vujović, Assoc. Prof.}

University of Montenegro,

Faculty of Mechanical Engineering Podgorica,

Dzordza Vasingtona bb, 81000 Podgorica, Montenegro

E-mail: aleksv@ac.me

\section{Jelena Jovanović, Assist. Prof.}

University of Montenegro,

Faculty of Mechanical Engineering Podgorica,

Dzordza Vasingtona bb, 81000 Podgorica, Montenegro

E-mail: sjelena@t-com.me

\section{Zdravko Krivokapić, Full Prof.}

University of Montenegro,

Faculty of Mechanical Engineering Podgorica,

Dzordza Vasingtona bb, 81000 Podgorica, Montenegro

E-mail: zdravkok@ac.me

\section{Sanja Peković, PhD}

University of Montenegro,

Faculty of Tourism and Hotel Management Kotor,

Stari grad 320,85 330 Kotor, Montenegro

E-mail: pekovic.sanja@yahoo.fr

\section{Mirko Soković, Full Prof}

University of Ljubljana,

Faculty of Mechanical Engineering,

Aškerčeva c. 12, 1000 Ljubljana, Slovenia

E-mail: mirko.sokovic@fs.uni-lj.si

\section{Davorin Kramar, Assist. Prof}

University of Ljubljana,

Faculty of Mechanical Engineering,

Aškerčeva c. 12, 1000 Ljubljana, Slovenia

E-mail: davorin.kramar@fs.uni-lj.si 
Appendix 1: Pearson correlation coefficients

\begin{tabular}{|c|c|c|c|c|c|c|c|c|c|c|c|c|c|c|c|c|c|c|}
\hline & 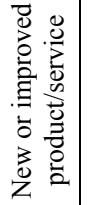 & 尝 & $\stackrel{\mathbb{N}}{\tilde{N}}$ & 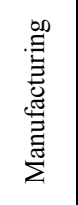 & 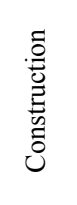 & 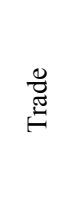 & $\sum_{\substack{0 \\
\infty}}^{.0}$ & 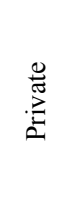 & $\frac{0}{0}$ & $\stackrel{㐅}{\Sigma}$ & $\begin{array}{l}\overrightarrow{1} \\
0 \\
0\end{array}$ & 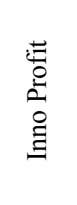 & 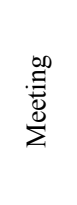 & 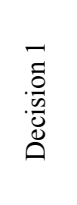 & 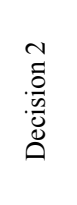 & $\begin{array}{l}m \\
\tilde{0} \\
\cdot \frac{1}{0} \\
\tilde{D} \\
0\end{array}$ & 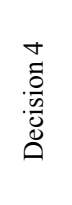 & $\begin{array}{l}n \\
\tilde{0} \\
\frac{0}{0} \\
\stackrel{0}{0} \\
0\end{array}$ \\
\hline $\begin{array}{l}\text { New or } \\
\text { improved } \\
\text { product/service }\end{array}$ & 1,00 & - & - & - & - & - & - & - & - & - & - & - & - & - & - & - & - & - \\
\hline Quality & 0,09 & - & - & - & - & - & - & - & - & - & - & - & - & - & - & - & - & - \\
\hline Size & 0,08 & 0,12 & 1,00 & - & - & - & - & - & - & - & - & - & - & - & - & - & - & - \\
\hline Manufacturing & 0,11 & 0,05 & $-0,01$ & 1,00 & - & - & - & - & - & - & - & - & - & - & - & - & - & - \\
\hline Construction & $-0,01$ & 0,02 & $-0,14$ & $-0,24$ & 1,00 & - & - & - & - & - & - & - & - & - & - & - & - & - \\
\hline Trade & 0,06 & $-0,13$ & 0,05 & $-0,35$ & $-0,18$ & 1,00 & - & - & - & - & - & - & - & - & - & - & - & - \\
\hline Service & $-0,13$ & $-0,04$ & 0,07 & $-0,52$ & $-0,26$ & $-0,37$ & 1,00 & - & - & - & - & - & - & - & - & - & - & - \\
\hline Private & 0,05 & $-0,11$ & $-0,31$ & 0,24 & 0,14 & 0,19 & $-0,46$ & 1,00 & - & - & - & - & - & - & - & - & - & - \\
\hline Public & $-0,16$ & 0,13 & 0,19 & $-0,27$ & $-0,16$ & $-0,11$ & 0,47 & $-0,77$ & 1,00 & - & - & - & - & - & - & - & - & - \\
\hline Mix & 0,15 & $-0,00$ & 0,22 & $-0,02$ & $-0,01$ & $-0,15$ & 0,09 & $-0,52$ & $-0,14$ & 1,00 & - & - & - & - & - & - & - & - \\
\hline Profit & 0,06 & $-0,06$ & 0,49 & $-0,18$ & 0,05 & 0,18 & $-0,00$ & $-0,11$ & 0,01 & 0,15 & 1,00 & - & - & - & - & - & - & - \\
\hline Inno Profit & 0,50 & $-0,04$ & $-0,04$ & 0,05 & 0,10 & 0,12 & $-0,20$ & 0,19 & $-0,16$ & $-0,09$ & $-0,12$ & 1,00 & - & - & - & - & - & - \\
\hline Meeting & 0,31 & $-0,19$ & 0,06 & 0,05 & $-0,10$ & 0,16 & $-0,10$ & 0,20 & $-0,25$ & 0,03 & 0,04 & 0,21 & 1,00 & - & - & - & - & - \\
\hline Decision 1 & $-0,12$ & 0,04 & $-0,20$ & 0,17 & $-0,09$ & 0,11 & $-0,19$ & 0,21 & $-0,14$ & $-0,14$ & $-0,06$ & 0,03 & 0,06 & 1,00 & - & - & - & - \\
\hline Decision 2 & 0,14 & 0,05 & 0,23 & $-0,04$ & 0,02 & 0,01 & 0,03 & $-0,05$ & $-0,01$ & 0,09 & 0,14 & $-0,05$ & 0,11 & $-0,34$ & 1,00 & - & - & - \\
\hline Decision 3 & 0,09 & 0,05 & $-0,02$ & $-0,01$ & $-0,02$ & 0,08 & $-0,04$ & 0,08 & $-0,01$ & $-0,11$ & $-0,09$ & 0,23 & 0,21 & $-0,27$ & $-0,45$ & 1,00 & - & - \\
\hline Decision 4 & 0,02 & $-0,10$ & $-0,08$ & $-0,03$ & $-0,06$ & $-0,09$ & 0,16 & $-0,21$ & 0,17 & 0,11 & $-0,09$ & $-0,09$ & $-0,03$ & $-0,08$ & $-0,14$ & $-0,11$ & 1,00 & - \\
\hline Decision 5 & $-0,17$ & $-0,11$ & $-0,03$ & $-0,09$ & 0,12 & $-0,18$ & 0,12 & $-0,14$ & 0,09 & 0,10 & 0,02 & $-0,18$ & $-0,41$ & $-0,21$ & $-0,35$ & $-0,27$ & $-0,09$ & 1,00 \\
\hline
\end{tabular}

